\title{
Identifying the Determinants for Attractiveness of Integrated Forms of Care from the Perspective of Health Care Professionals
}

\author{
Eva Krczal
}

Department for Economy and Health, Danube University Krems, Krems 3500, Austria

\begin{abstract}
Fostering integration between caregivers in the ambulatory sector involves transforming the institutional, organizational and technical framework but also redesigning the work performed by health care professionals. Empirical research on the implementation of integrated care highlights professional engagement and commitment as a key success factor during the change process. Although a mismatch of motives during the integration process is often reported only a few studies have explored motivational aspects of health care integration. The aim of this study is to explore motivational factors for health care professionals in order to identify the determinants of attractiveness of integrated forms of care. An online-questionnaire was developed to identify the most important motivational factors for health care professionals and to reflect their perceptions on the attractiveness of interdisciplinary forms of care. The sample includes practicing physicians (general practitioners and specialists), practicing nurses and non-physician professions (physiotherapists, midwives, speech therapists, occupational therapists). Findings suggest that health care professionals are highly motivated by intrinsic motivators. Physicians turned out to be the most reluctant group towards integrated care models. Participating in integrated forms of care would challenge working independently which represents a strong motivator. The responses of nurses suggest that they are the most favorable group. Integrated care forms would be attractive offering more possibilities for social relationships, expanding responsibilities and challenging work. Results support the importance of health workforce engagement and participation in planning health care integration.
\end{abstract}

Key words: Motivation, human resource management, employee engagement, occupational choice, implementing integrated care.

\section{Introduction}

\subsection{Background}

The growing prevalence of chronic diseases and an aging population have led to an increasing number of elderly and multi-morbid patients in high income countries [1, 2]. Patients with complex needs (e.g., multiple morbidities) are challenging professional bodies, individual practitioners and regulators to provide health care services more responsive to their specific needs for comprehensive and continuous care $[3,4]$. Integrated care strategies are considered as a means to improve quality (in terms of impact on health outcomes and responsiveness to patient needs)

Corresponding author: Eva Krczal, doctor in economics and social sciences, research fields: health care management, organizational behavior, motivation. and to ensure cost efficiency and access to care [5-7]. The primary care sector plays an important role in establishing integrated care structures because it builds on the principles of continuous, comprehensive and coordinated care [8-12]. In primary care, different organizational forms of care provision can be found. The sector is mainly characterized by independent self-employed contractors operating in solo practice with some countries providing primary care clinics [5]. Fostering integration between caregivers in the ambulatory sector involves transforming the institutional, organizational and technical framework. Structural and technical changes also have an impact on the individual work performed by health care professionals. Redesigning the work towards health systems integration includes changes in the working conditions, skills, role definitions and responsibilities 
of the health care staff $[13,14]$. The importance of human resources as a crucial input factor with a strong impact on the organizations' overall performance is well recognized in all industries [14]. This also applies to the health services industry, where most health interventions depend on the skills and knowledge of the health care personnel $[15,16]$. Given the health care professionals' involvement in all aspects of care the success of integrated care strategies depends to a large extend on the efforts of the health workforce [17]. Empirical research on the implementation of integrated care highlighted professional engagement and commitment as a key success factor during the change process [18-20]. Health care managers and regulating bodies are challenged to motivate health care professionals to join integrated care models, remain there and perform to the desired goals. Offering health care professionals a workplace that meets their individual needs and values may facilitate their commitment and engagement in integrated care models.

\subsection{Theory/Literature Review}

Behavioral scientists explain motivational behavior to be arising from a certain need or desire [21]. Motivation results into a behavior that is directed towards achieving certain goals [22]. Motivational drivers in an organizational context are usually a combination of internal forces and external stimulators in form of incentives [23]. Motivational theories provide the conceptual background for the links and causality chains between drivers of motivation and motivational outcomes [24]. Together with empirical evidence they can be used by managers and regulators for designing motivational strategies.

Leading motivational theories are based on the work by Maslow [25], Herzberg [26], Aderfer [27] and McClelland [28]. Referred to as content theories of motivations they are highlighting the factors that motivate an individual. Building on the work of Maslow Aderfer's ERG-Theory further developed
Maslow's theory of needs to be better suited for an organizational context [29]. According to Aderfer motivation stems from striving for certain basic needs [27]. These needs can be categorized into three groups. "Existence" needs relate to material and physical needs such as rewards, remuneration and working conditions. "Relatedness" needs refer to social needs including the need for interpersonal relationships, receiving appreciation and recognition. The third category, "growth" needs refer to the desire for personal development and productivity. McClelland's acquired needs theory highlights another category: the need for power which comprises the desire for responsibility and to influence or control others [28]. Herzberg's two-factor theory adds a two-dimensional perspective and distinguishes between motivators and hygienes [30]. Motivators are intrinsic factors that are arising from the work itself and are usually linked to opportunities for responsibility, growth, achievement and intellectual challenge. Motivators promote fulfilment and job satisfaction. Hygienes are extrinsic factors like payment, job security and promotion opportunities. They result in job dissatisfaction when expectations are not met but don't necessarily lead to higher motivation when present. Regarding occupational choices Ratanawongsa et al. [31] concluded from a literature review on motivation of physicians that extrinsic as well as intrinsic factors are considered for professional choices and decisions on career paths.

Vroom's expectancy theory represents a leading process theory of motivation. According to Vroom's [32] theory the employees' effort and performance is linked to expected rewards. The more positive the reward the more likely the employee will be motivated. Vroom assumes a link between the motives of individuals and their occupational preferences which is moderated by assumptions about the subjective probability and expected costs of their attainment.

Empirical studies on motivation of health care workforce have been focused mostly on exploring the 
relationships between motivation, job satisfaction, intention to stay or leave and performance. Findings from research studies on motivation of the health care workforce are highlighting the importance of intrinsic factors. A study of motivational factors for physicians ranked interesting work, appreciation of work done, empowerment and autonomy as top motivators while good wages were reported to be of minor importance [33]. Another study identified achievements as the highest motivator for physicians and nurses while remuneration was a significant incentive only for professionals in managerial positions [34]. A study targeting the nursing personnel reported that motivation decreases when nurses are not empowered and not autonomous in activity and their competencies are not applied in full value [35]. Another empirical study reported contradictory results. A survey conducted with physicians and nursing staff reported that job attributes encompassing creativity opportunities, skill exploitation and decision-making as the lowest motivator ranked by both groups [36]. Concerning nurses a strong motivational effect of recognition \& feedback and social relationships has been observed [35, 37].

In face of the extensive research on health workforce motivation the issue has been rarely discussed in the context of their engagement in integrated care initiatives. In fact, much of the research on the implementation of integrated care is concentrated on structural and process challenges and on defining barriers and enabling care integration. Research studies exploring the success factors for healthcare integration emphasized the importance of physician integration [38, 39]. A qualitative research study from the UK reported that opposition from the GPs was identified as a major barrier to the implementation process [18]. The risk of facing negative consequences, for example loss of power and autonomy or a decrease in earnings may induce resistance to change [40-42]. Participation in integrated care networks requires extended management responsibilities and new roles in care coordination which not all physicians might be capable or willing to assume [40, 43]. Although a mismatch of motives during the integration process is often reported only a few studies have explored motivational and socio-cognitive aspects of health care integration [44]. The present study attempts to contribute to a better understanding of the links between health workforce motivation and their engagement in health care integration.

\subsection{Aim of the Study}

The aim of the study was to explore motivational factors for health care professionals in order to identify the determinants of attractiveness of integrated forms of care. In designing our research study we were guided by two assumptions. Health care professionals can be attracted by integrated forms of care when firstly, they offer a working environment that meets their needs and expectations and secondly, the individual goals of health care professionals can be better achieved in integrated care models (the expected positive rewards exceed the expected negative rewards). This led us to the following research questions:

- What motivational factors are most important to health care professionals?

- To what extent are their expectations met at the current workplace?

- What are their perceptions on the attractiveness of interdisciplinary forms of care?

- How do the perceptions compare between the professional groups?

Answers to these questions contribute to a better understanding of the motivational drivers for health care professionals and may be beneficial to the design of attractive workplaces in integrative forms of care.

\section{Materials and Methods}

\subsection{Questionnaire Development}

For the present research an online-questionnaire 
was developed to identify the most important motivational factors for health care professionals and to reflect their perceptions on the attractiveness of interdisciplinary forms of care. The challenge was to develop a questionnaire that was able to capture the perceptions of all three major professional groups (physicians, nurses and non-physician professions). Item selection was guided by motivational theory, especially Herzberg's Two-Factor Theory [26], Adelfers ERG theory [27] and questionnaires used in previous studies on motivational factors in health care settings [24, 33-37, 45-47]. Furthermore the work value questionnaire by Elizur et al. [48] was studied. This questionnaire was originally deployed to identify cross cultural differences in work values and was considered a valuable instrument for capturing possible differences among professional groups in health care.

To enhance content validity, the questionnaire was presented independently to three experts in the field of health care management and one expert in the field of human resource management and psychology. Experts were asked to judge the questionnaire for appropriateness, clarity and completeness. The draft questionnaire was also presented to three focus groups consisting of different health care professions. The focus groups were asked to assess the questionnaire with regard to appearance, clarity and completion time. Finally the questionnaire was pilot-tested with a sample of 104 health care professionals including physicians, nurses and other non-physician health care professions (physiotherapists and speech therapists). The questionnaire was easily understood and completed by the pilot-test sample. Analytical tests resulted in the removal of six ambiguous and redundant items.

\subsection{Instrument Description}

The definitive research instrument consisted of twenty closed ended-items referring to work attributes and working conditions, that previous research suggested might be associated with motivation of the healthcare workforce. All items were phrased neutrally as statements. The complete list of the items is presented in Table 1. Respondents were asked to rate each item in three ways. First the respondents were asked to rate the importance of each item for their motivation to strive for high performance. The response option was a six-point-scale anchored at one end by "very important" and at the other end by "very unimportant". Second respondents were asked to rate to what extend their expectations were met concerning that item on their current workplace. The response option was an eleven-point-slider anchored at one end by " $0 \%$ " and at the other end by " $100 \%$ ". Third, respondents were asked to assess whether they expect the item to change when participating an integrated care model. The response option was for example "I expect that receiving recognition for my work will: increase-stay the same-decrease". The questionnaire also included a single question. Respondents were asked to rate their overall work motivation: "How motivated do you feel in your present job in general?” The response option was an eleven-point-slider anchored at one end by " $0 \%$ " and at the other end by "100\%”.

\subsection{Sample and Data Collection}

The questionnaire was sent in a link via a web survey software program. An email was sent containing a short explanation of the study, ensuring anonymity and including a link to enter the survey. No incentive was offered for completing the questionnaire. One week after the initial email a reminder was sent to non-respondents. The sample included practicing physicians (general practitioners and specialists), practicing nurses and other non-physician professions (physiotherapists, midwives, speech therapists, occupational therapists). Overall 1,244 physicians, nurses and non-physician health care professionals were selected (non-random sample). In total 267 health care professionals responded to the questionnaire, with an overall response rate of $22 \%$. 
The response rates were $14 \%$ for the physicians ( $\mathrm{n}=$ 49), $18 \%$ for nurses $(n=85)$ and $32 \%$ for non-physician professions $(\mathrm{n}=133)$.

\subsection{Analytical Methods}

Internal consistency reliability was tested via Cronbach's Alpha coefficient. Reliability for the entire questionnaire has been established at 0.87 . Average importance (importance of the item to strive for high performance) and satisfaction scores (degree to which expectations are met) were calculated and compared to evaluate the largest gaps between respective items. An explanatory factor analysis using principal component analysis with varimax rotation was performed to group the twenty items into a smaller number of factors. Reliability for each factor ranged from 0.61 to 0.84 . Pearson correlations were calculated between each factor and overall work motivation to reveal the most important motivational factors. One-way ANOVA and parametric t-tests were performed for comparisons between professional groups. Frequency distributions were prepared to reflect the expected consequences from participating in integrated forms of care. All analyses were performed with SPSS version 24 .

\section{Results}

The explanatory factor analysis extracted five motivational factors: "social relationships", "work-related factors", "career", "recognition \& feedback" and "security". Table 1 illustrates the factor loadings and the interpretation of factors. The five-factor solution captured $60.46 \%$ of the total variance in responses. Two variables were not included in the extracted factors. Another two variables of factor "career

Table 1 Factor analysis of motivation factors for health care professionals.

\begin{tabular}{|c|c|c|c|c|c|}
\hline Item & $\begin{array}{l}\text { Social } \\
\text { relationships }\end{array}$ & $\begin{array}{l}\text { Work-related } \\
\text { factor }\end{array}$ & Career & $\begin{array}{l}\text { Recognition } \\
\text { \& feedback }\end{array}$ & Security \\
\hline Work in a team that shares the same goals and values & 0.826 & & & & \\
\hline Good relationships with peers and employees & 0.813 & & & & \\
\hline Mutual support by peers & 0.806 & & & & \\
\hline Interesting and meaningful work & & 0.795 & & & \\
\hline Have fun at work & & 0.726 & & & \\
\hline Challenging work, exploiting skills and expertise & & 0.654 & & & \\
\hline Personal growth & & 0.640 & & & \\
\hline Working independently and with responsibility & & 0.616 & & & \\
\hline Career opportunities & & & 0.673 & & \\
\hline Modern technological equipment and infrastructure & & & 0.649 & & \\
\hline Performance-oriented pay & & & 0.553 & & \\
\hline Opportunity to expand professional network & & & 0.508 & & \\
\hline \multicolumn{6}{|l|}{ Orientation by explicit guidelines and goals } \\
\hline Appreciation and recognition for one's work & & & & 0.771 & \\
\hline Feedback regarding the results of one's work & & & & 0.710 & \\
\hline Being proud of one's work & & & & 0.651 & \\
\hline Good image of practice or organization & & & & 0.631 & \\
\hline Guaranteed basic income & & & & & 0.805 \\
\hline Job security & & & & & 0.804 \\
\hline \multicolumn{6}{|l|}{ Reconciling work and private life } \\
\hline Eigenvalues & 5.82 & 2.18 & 1.74 & 1.28 & 1.13 \\
\hline No. & 255 & 251 & 253 & 252 & 254 \\
\hline Cronbach's $\alpha$ & 0.84 & 0.76 & 0.61 & 0.75 & 0.79 \\
\hline
\end{tabular}

Extraction method: principal component analysis. Rotation method: Varimax with Kaiser normalization. 
opportunities" did not meet satisfactory factory loadings ( 0.55 and 0.51 ). It was defined that a variable can be assigned to a factor if its loading is equal to or above 0.6. Consequently, these variables were not included in further analysis.

Average importance (importance of the item to strive for high performance) and satisfaction scores (degree to which expectations are met) were calculated. Table 2 illustrates responses from the three professional groups regarding importance of the factor as a motivator and the degree to which the expectations of respondents are met. In terms of the entire sample the three top motivators can be found in the work-related factor: "interesting and meaningful work", "challenging work, exploiting skills and expertise" and "working independently and with responsibility". Interestingly, the three top motivators also yield the highest satisfaction scores in terms of degree to which the respondent's expectations are met at the current workplace. On a scale ranging from $0-100 \%$ their expectations concerning "working independently and with responsibility” are highest met

Table 2 Mean scores of reported importance as a motivating factor and the degree of expectations met for the entire sample and by professional group.

\begin{tabular}{|c|c|c|c|c|c|c|c|c|c|}
\hline \multirow[b]{2}{*}{$\begin{array}{l}\text { Motivating } \\
\text { factor }\end{array}$} & \multirow[t]{2}{*}{ Item } & \multicolumn{2}{|c|}{$\begin{array}{c}\text { Total } \\
\mathrm{N}=267\end{array}$} & \multicolumn{2}{|c|}{$\begin{array}{c}\text { Physicians } \\
\mathrm{N}=49\end{array}$} & \multicolumn{2}{|c|}{$\begin{array}{l}\text { Nurses } \\
\mathrm{N}=85\end{array}$} & \multicolumn{2}{|c|}{$\begin{array}{c}\text { Non-physician } \\
\text { professions } \\
\mathrm{N}=133\end{array}$} \\
\hline & & $\begin{array}{l}\mathrm{M}^{\mathrm{a}} \\
\text { Mean (SD) }\end{array}$ & $\begin{array}{l}\mathrm{E}^{\mathrm{b}} \\
\text { Mean (SD) }\end{array}$ & $\begin{array}{l}\mathrm{M}^{\mathrm{a}} \\
\text { Mean (SD) }\end{array}$ & $\begin{array}{l}E^{b} \\
\text { Mean (SD) }\end{array}$ & $\begin{array}{l}\mathrm{M}^{\mathrm{a}} \\
\text { Mean (SD) }\end{array}$ & $\begin{array}{l}E^{\mathrm{b}} \\
\text { Mean (SD) }\end{array}$ & $\begin{array}{l}\mathrm{M}^{\mathrm{a}} \\
\text { Mean (SD) }\end{array}$ & $\begin{array}{l}E^{b} \\
\text { Mean (SD) }\end{array}$ \\
\hline \multirow[t]{3}{*}{$\begin{array}{l}\text { Social } \\
\text { relationships }\end{array}$} & Teamwork & $5.14(1.17)$ & $\begin{array}{l}66.74 \\
(29.73)\end{array}$ & $5.15(1.07)$ & $\begin{array}{l}80.00 \\
(24.49)\end{array}$ & $5.76(0.67)$ & $\begin{array}{l}61.11 \\
(31.80)\end{array}$ & $5.05(1.22)$ & $\begin{array}{l}65.42 \\
(30.02)\end{array}$ \\
\hline & Relationships & $5.25(1.07)$ & $\begin{array}{l}72.61 \\
(28.74)\end{array}$ & $5.54(0.66)$ & $\begin{array}{l}88.18 \\
(12.50)\end{array}$ & $5.67(0.71)$ & $\begin{array}{l}66.67 \\
(30.82)\end{array}$ & $5.15(1.15)$ & $\begin{array}{l}70.97 \\
(29.75)\end{array}$ \\
\hline & Peer support & $5.35(0.93)$ & $\begin{array}{l}69.78 \\
(29.13) \\
\end{array}$ & $5.46(0.78$ & $\begin{array}{l}83.64 \\
(15.02) \\
\end{array}$ & $5.78(0.67)$ & $\begin{array}{l}62.22 \\
(36.67) \\
\end{array}$ & $5.27(0.98)$ & $\begin{array}{l}68.61 \\
(29.42) \\
\end{array}$ \\
\hline \multirow[t]{5}{*}{$\begin{array}{l}\text { Work-related } \\
\text { factor }\end{array}$} & $\begin{array}{l}\text { Interesting \& } \\
\text { meaningful }\end{array}$ & $5.79(0.41)$ & $\begin{array}{l}83.30 \\
(19.31)\end{array}$ & $5.54(0.52)$ & $\begin{array}{l}80.00 \\
(18.10)\end{array}$ & $5.78(0.44)$ & $\begin{array}{l}78.89 \\
(26.19)\end{array}$ & $5.84(0.37)$ & $\begin{array}{l}84.38 \\
(18.71)\end{array}$ \\
\hline & Fun at work & $5.60(0.76)$ & $\begin{array}{l}78.83 \\
(23.87)\end{array}$ & $5.46(0.88)$ & $\begin{array}{l}72.50 \\
(23.79)\end{array}$ & $5.56(0.73)$ & $\begin{array}{l}75.56 \\
(24.04)\end{array}$ & $5.63(0.76)$ & $\begin{array}{l}80.27 \\
(23.98)\end{array}$ \\
\hline & $\begin{array}{l}\text { Challenge, skill } \\
\text { exploitation }\end{array}$ & $5.65(0.6)$ & $\begin{array}{l}79.57 \\
(19.89)\end{array}$ & $5.54(0.52)$ & $\begin{array}{l}79.17 \\
(15.05)\end{array}$ & $5.89(0.33)$ & $\begin{array}{l}77.78 \\
(23.33)\end{array}$ & $5.64(0.63)$ & $\begin{array}{l}79.86 \\
(20.38)\end{array}$ \\
\hline & Personal growth & $5.30(0.96)$ & $\begin{array}{l}73.70 \\
(25.15)\end{array}$ & $5.23(0.73)$ & $\begin{array}{l}69.09 \\
(24.68)\end{array}$ & $5.44(1.01)$ & $\begin{array}{l}74.44 \\
(34.32)\end{array}$ & $5.29(1.00)$ & $\begin{array}{l}74.31 \\
(24.25)\end{array}$ \\
\hline & $\begin{array}{l}\text { Working } \\
\text { independently }\end{array}$ & $5.65(0.60)$ & $\begin{array}{l}88.83 \\
(17.09) \\
\end{array}$ & $5.62(0.51)$ & $\begin{array}{l}85.00 \\
(14.46) \\
\end{array}$ & $5.78(0.44)$ & $\begin{array}{l}86.67 \\
(13.23) \\
\end{array}$ & $5.64(0.63)$ & $\begin{array}{l}89.73 \\
(17.95) \\
\end{array}$ \\
\hline \multirow[t]{2}{*}{ Career } & $\begin{array}{l}\text { Career } \\
\text { opportunities }\end{array}$ & 4.60 (1.05) & $\begin{array}{l}62.28 \\
(26.94)\end{array}$ & $4.92(1.12)$ & $\begin{array}{l}75.45 \\
(16.95)\end{array}$ & $4.22(0.83)$ & $\begin{array}{l}56.67 \\
(28.72)\end{array}$ & 4.59 (1.05) & $\begin{array}{l}60.97 \\
(27.64)\end{array}$ \\
\hline & $\begin{array}{l}\text { Equipment \& } \\
\text { infrastructure }\end{array}$ & $4.61(1.11)$ & $\begin{array}{l}67.63 \\
(25.43)\end{array}$ & $5.31(0.63)$ & $\begin{array}{l}83.64 \\
(23.35)\end{array}$ & 4.33 (1.23) & $\begin{array}{l}56.67 \\
(23.98)\end{array}$ & 4.52 (1.13) & $\begin{array}{l}66.58 \\
(25.12)\end{array}$ \\
\hline \multirow[t]{4}{*}{$\begin{array}{l}\text { Appreciation \& } \\
\text { feedback }\end{array}$} & $\begin{array}{l}\text { Appreciation \& } \\
\text { recognition }\end{array}$ & $5.46(0.68)$ & $\begin{array}{l}77.31 \\
(21.88)\end{array}$ & $5.38(0.77)$ & $\begin{array}{l}82.73 \\
(12.72)\end{array}$ & $5.78(0.44)$ & $\begin{array}{l}70.00 \\
(28.28)\end{array}$ & $5.44(0.69)$ & $\begin{array}{l}77.40 \\
(22.11)\end{array}$ \\
\hline & Feedback & $5.34(0.86)$ & $\begin{array}{l}69.47 \\
(22.88)\end{array}$ & $5.08(0.86)$ & $\begin{array}{l}70.00 \\
(24.12)\end{array}$ & $5.67(0.50)$ & $\begin{array}{l}64.44 \\
(21.86)\end{array}$ & $5.34(0.86)$ & $\begin{array}{l}70.00 \\
(23.03)\end{array}$ \\
\hline & $\begin{array}{l}\text { Proud of one`s } \\
\text { work }\end{array}$ & $5.14(1.51)$ & $\begin{array}{l}78.57 \\
(25.24)\end{array}$ & $5.00(0.85)$ & $\begin{array}{l}81.00 \\
(19.12)\end{array}$ & $5.67(0.50)$ & $\begin{array}{l}75.56 \\
(30.05)\end{array}$ & $5.10(1.24)$ & $\begin{array}{l}78.61 \\
(25.64)\end{array}$ \\
\hline & Good image & $5.41(0.68)$ & $\begin{array}{l}78.17 \\
(23.08)\end{array}$ & $5.62(0.65)$ & $\begin{array}{l}87.27 \\
(15.55)\end{array}$ & $5.56(0.53)$ & $\begin{array}{l}67.78 \\
(24.89)\end{array}$ & $5.36(0.70)$ & $\begin{array}{l}78.08 \\
(23.49)\end{array}$ \\
\hline \multirow[t]{2}{*}{ Secutity } & $\begin{array}{l}\text { Guaranteed } \\
\text { income }\end{array}$ & $\begin{array}{l}5.17 \\
(10.23)\end{array}$ & $\begin{array}{l}69.57 \\
(32.51)\end{array}$ & $5.00(0.91)$ & $\begin{array}{l}79.09 \\
(23.86)\end{array}$ & $5.33(0.50)$ & $\begin{array}{l}75.56 \\
(40.35)\end{array}$ & $5.18(1.09)$ & $\begin{array}{l}67.36 \\
(32.67)\end{array}$ \\
\hline & Job Security & $5.07(0.98)$ & $\begin{array}{l}75.98 \\
(27.46)\end{array}$ & $5.15(0.80)$ & $\begin{array}{l}75.45 \\
(20.67)\end{array}$ & $5.00(1.12)$ & $\begin{array}{l}72.22 \\
(39.30)\end{array}$ & $5.07(1.01)$ & $\begin{array}{l}76.53 \\
(27.02)\end{array}$ \\
\hline
\end{tabular}


(89\%) followed by "interesting and meaningful work" (83\%) and “challenging work, exploiting skills and expertise” (80\%). The bottom three motivators were items from the career factor: "career opportunities" and "modern technological equipment and infrastructure" and from the security factor: "job security”. Regarding the degree to which their expectations are met at the current workplace, items of the career factor and one item from the social relationship factor were rated very low by the respondents. "Career opportunities" received the lowest scores in expectations met (62\%) followed by "work in a team that shares the same goals and values" (67\%) and "modern technological equipment and infrastructure” (68\%).

For each motivation factor, summarized scores of the responses of expectations met were calculated on a 0-100\% scale, with higher scores corresponding to a higher degree of expectations met. Pearson correlations were calculated between each factor and overall motivation at work. Correlation analysis highlighted the importance of the work-related factor. Results revealed a strong positive correlation between the work-related factor and overall motivation at work ( $r=0.802)$. Moderate positive correlations have been found with the recognition \& feedback factor $(r=$ $0.693)$, the social relationships factor $(r=0.494)$ and the career factor $(r=0.486)$. The security factor showed a weak positive correlation $(r=0.415)$. All correlations were highly significant at the $p<0.000$ level.

One-way ANOVA and parametric t-tests were performed to identify statistically significant differences in the responses between professional groups. The results are presented in Table 3. ANOVA revealed significant differences in all factors except security. T-tests were run to explore the differences between the subgroups. The importance of the work-related factor as a motivational driver was ranked high in all professional groups and no statistically significant difference was observed. Expectations on work-related factors were met to a higher degree in the non-physician profession sample compared to nurses $(p=0.001)$ and physicians ( $p=$ 0.047). Significant differences in responses have been observed in the recognition \& feedback factor. Nurses $(p=0.008)$ and non-physician professions $(p=0.001)$ reported being more motivated by recognition \& feedback than physicians. Expectations met concerning recognition \& feedback were the highest in physician responses and the lowest in nurses' responses. Social relationships appeared to motivate nurses more than other professions with significant differences between nurses and non-physician professions ( $p=0.007$ ). Career was the most important to physicians with significant differences in responses

Table 3 Differences in reported importance of motivational drivers and degree of expectations met by professional group.

\begin{tabular}{|c|c|c|c|c|c|c|c|c|}
\hline \multirow{3}{*}{ Factor derived } & \multicolumn{4}{|c|}{ Importance for motivation $^{\mathrm{a}}$} & \multicolumn{4}{|c|}{ Degree of expectations met $^{\mathrm{b}}$} \\
\hline & & Physicians & Nurses & $\begin{array}{l}\text { Non-physician } \\
\text { profession }\end{array}$ & & Physicians & Nurses & $\begin{array}{l}\text { Non-physician } \\
\text { profession }\end{array}$ \\
\hline & $\mathrm{F}$ & Mean (SD) & Mean (SD) & Mean (SD) & $\mathrm{F}$ & Mean (SD) & Mean (SD) & Mean (SD) \\
\hline $\begin{array}{l}\text { Work-related } \\
\text { factor }\end{array}$ & 1.831 & $5.42(0.46)$ & $5.44(0.42)$ & $5.47(0.46)$ & $7.016^{* *}$ & 75.67 (16.29) & 78.67 (20.95) & 81.45 (17.57) \\
\hline $\begin{array}{l}\text { Recognition \& } \\
\text { feedback }\end{array}$ & $6.119 * *$ & $5.27(0.57)$ & $5.67(0.31)$ & $5.31(0.68)$ & $14.312^{* * *}$ & $79.24(14.47)$ & $69.44(24.30)$ & $75.93(18.90)$ \\
\hline $\begin{array}{l}\text { Social } \\
\text { relationships }\end{array}$ & $3.083^{*}$ & $5.39(0.71)$ & $5.74(0.66)$ & $5.16(1.01)$ & 0.376 & $83.40(15.62)$ & 63.33 (32.79) & $78.33(28.25)$ \\
\hline Career & $4.119 *$ & $8.88(1.91)$ & $6.67(2.29)$ & $7.36(2.32)$ & 0.799 & $58.46(14.05)$ & 44.44 (13.57) & $51.23(14.14)$ \\
\hline Security & 1.362 & $5.08(0.76)$ & $5.17(0.75)$ & $5.12(0.92)$ & 0.081 & $77.27(21.26)$ & 73.89 (39.59) & $71.51(17.76)$ \\
\hline
\end{tabular}

One-way ANOVA; *p<0.05; **p<0.01; ***p<0.001.

${ }^{a}$ Scores ranging from 1-6 with higher scores corresponding to higher importance.

${ }^{\mathrm{b}}$ Scores ranging from 0-100\% with higher scores corresponding to higher degree of expectations met. 
compared to nurses $(p=0.006)$. Physicians responded that their expectations concerning this factor are met to a high degree compared to the other professional groups, however no statistically significant difference was observed.

In the last part of the questionnaire respondents were asked to refer to the expected changes from participation of an integrated care model. Considering the lack of a long standing tradition or experience with integrated care in the Austrian health care system answering options were kept very simple. However, they were assumed to provide valuable information on the perceived relationship between positive and negative "rewards" expected from participating in integrated care models. Modes were calculated to capture the most frequent responses. The majority of the physicians and non-physician professions expected that "working independently and with responsibility" would decrease. This item represented an essential motivator and has been assigned to the work-related factor. Items that are expected to increase are affiliated to all motivational factors (work-related factor, social relationships, recognition \& feedback and career) except the security factor. Responding physicians most frequently expected that "having fun at work" and "mutual support by peers" would increase. A certain ambiguity in responses of physicians derived from a group of respondents (22\%) expecting "Working independently and with responsibility" would decrease while "having fun at work" would increase. Responding nurses and non-physician professions most frequently expected that "challenging work, exploiting skills and expertise" and "working in a team that shares the same goals and values" would increase. Responding non-physician professions additionally expected that "good relationships with peers and employees", "being proud of one's work", "good image of practice or organization" and "modern technological equipment and infrastructure" would increase. Referring to a general question whether professional and personal goals could be better pursued in integrated care models the majority of responding nurses (82\%) and non-physician professions (70\%) agreed whereas the majority of responding physicians (61\%) disagreed.

\section{Discussion}

Findings suggest that health care professionals were highly motivated by intrinsic motivators. Extrinsic factors have not been considered as highly compelling motivational drivers. Results are in line with Herzberg's two-factor theory and similar empirical research on health care workforce motivation highlighting the importance of intrinsic factors. The strong motivational effect of work-related factors, empowerment and autonomy for physicians was reported by Conrad et al. [33] and Kontodimopoulos et al. [34]. Empirical work exploring motivational drivers for nurses identified work-related factors, empowerment and autonomy as well as recognition \& feedback and social relationships for nurses as top motivators [34, 35, 37]. One survey reported contradictory results, ranking job attributes as the lowest motivator for physicians and nurses [36].

Participating in integrated forms of care would challenge working independently which represented a strong motivator to respondents. Results suggest that this factor could become a critical issue in the implementation process especially for physicians and non-physician professions. Results support the importance of health workforce engagement and participation in planning integration. Organizational structures should allow for their preferences to work independently and with responsibility.

Physicians turned out to be the most reluctant group towards integrated care models. Their expectations met were the highest in all categories except work-related factors. They could be attracted by creating interesting and challenging workplaces where they have the possibility to concentrate on their core profession and benefit from a closer collaboration with peers. 
Non-physician professions reported a number of positive outcomes associated with integrated care forms. They could be attracted by intrinsic factors (challenging work), social relationships (teamwork, collaboration with peers) and the benefits of synergy effects (better technological equipment and infrastructure, increase in reputation).

The responses of the nurses suggest that they were the most favorable group to participate in integrated care models. Recognition \& feedback and social relationships were more important to nurses than to the other health professions. However, their expectations for these two factors were met to a lower degree compared to the other professional groups. Integrated care forms would be attractive to them offering more possibilities for social relationships (teamwork, collaboration with teams). Furthermore, integrated care models are often expanding the responsibilities and roles of nurses offering them better opportunities for challenging work and recognition of their profession.

\section{Limitations and Future Research}

The sample of this study could have implications on the generalizability of the results. Respondents were postgraduate students or alumni enrolled in master programs. This could induce similarities in working motives and attitudes. Furthermore, differences in the return rate between the different health care professions pose limitations on the generalizability of the results obtained. Our findings require further exploration, perhaps via a larger sample of health care professionals. Exploring the motives and preferences of the health care staff regarding integrated forms of care offers a wide range of research opportunities. Further studies, particularly ones using qualitative methods could contribute to the understanding of the decisional processes of health care professionals when opting for participating in integrated forms of care.

\section{Conclusions}

A better understanding of motivational factors and work values contributes to designing integrated forms of care in a way to respond to the needs and work-related motives of the health care workforce. Paying attention to the motivators and work preferences can facilitate the dissemination of integrated forms of care. The results of the study suggest a number of factors that seemed to be crucial in obtaining the engagement and commitment of health care professionals: working independently and with responsibility, challenging work and social relationships. Physicians could be attracted by creating interesting and challenging workplaces where they can benefit from a closer collaboration with peers and retain a certain degree of independence. For the nursing profession integrated care forms would be attractive in terms of more possibilities for social relationships, expanded responsibilities and better opportunities for challenging work and recognition. Non-physician professions could be attracted by intrinsic factors and social relationships in addition to the benefits of synergy effects when integrating care. Further research exploring motives and preferences of health care professionals when integrating care would contribute to a better understanding of the behavioral aspects of health care integration.

\section{References}

[1] Nolte, E., and Pitchforth, E. 2014. What Is the Evidence on the Economic Impacts of Integrated Care? Copenhagen: WHO Regional Office for Europe.

[2] Coleman, E. A. 2002. "Challenges of Dystems of Care for Frail Older Persons: The United States of America Experience.” Aging Clinical and Experimental Research 14 (4): 233-8.

[3] Gröne, O., and Garcia-Barbero, M. 2001. "Integrated Care: A Position Paper of the WHO European Office for Integrated Health Care Services.” International Journal of Integrated Care 1 (2). Accessed September 30, 2016. http://doi.org/10.5334/ijic.28.

[4] Kodner, D. L. 2006. "Whole-System Approaches to Health and Social Care Partnerships for the Frail Elderly: An Exploration of North American Models and Lessons.” Health and Social Care Community 14 (5): 384-90.

[5] Hofmacher, M., Oxley, H., and Rusticelli, E. 2007. Improved Health System Performance through Better 
Care Coordination. OECD Health Working Papers.

[6] Leibert, M. 2011. "Performance of Integrated Delivery Systems: Quality, Service and Cost Implications." Leadership in Health Services 24 (3): 196-206.

[7] Kodner, D. L. 2009. "All Together Now: A Conceptual Exploration of Integrated Care.” Healthcare Quarterly 13: 6-15.

[8] The World Health Report. 2008. Primary Health Care Now More Than Ever. Geneva: World Health Organization. Accessed October 15, 2016. http://apps.who.int/iris/bitstream/10665/108066/1/E5847 4.pdf.

[9] World Health Organization Europe. 1998. "Framework for Professional and Administrative Development of General Practice/Family Medicine in Europe.” Kopenhagen: World Health Organization Europe. Accessed October 15, 2016. http://apps.who.int/iris/bitstream/10665/108066/1/E5847 4.pdf.

[10] Valentijn, P. P., Shepman, S. M., Opheij, W., and Bruijnzells, M. A. 2013. "Understanding Integrated Care: A Comprehensive Conceptual Framework Based on the Integrative Functions of Primary Care.” International Journal of Integrated Care 13 (1). Accessed September 27,

2016. http://www.ijic.org/articles/abstract/10.5334/ijic.886/.

[11] Mur-Veeman, I., van Raak, A., and Paulus, A. 2008. "Comparing Integrated Care Policy in Europe: Does Policy Matter?” Health Policy 85: 172-83.

[12] Gask, L. 2005. "Overt and Covert Barriers to the Integration of Primary and Specialist Mental Health Care.” Social Science and Medicine 61: 1785-94.

[13] Bohmer, R. M. J., and Imison, C. 2013. "Lessons from England's Health Care Workforce Redesign: No Quick Fixes.” Health Affaires 32 (11): 2025-31.

[14] Rigoli, F., and Dussault, G. 2003. "The Interface between Health Sector Reform and Human Resources in Health.” Human Resources on Health 1 (9). Accessed September 16 ,

2016. https://www.ncbi.nlm.nih.gov/pmc/articles/PMC305361/.

[15] Dussault, G., and Dubois, C. A. 2003. "Human Resources for Health Policies: A Critical Component in Health Policies”. Human Resources on Health 1 (1). Accessed September 16, 2016. https://www.ncbi.nlm.nih.gov/pmc/articles/PMC166115/.

[16] Busetto, L., Calciolari, S., Gonzalez-Ortiz, L. G., Luijkx, K., and Vrijhoef, B. 2017. "Integrated Care and the Health Workforce." In Handbook of Integrated Care, edited by V. Amelung, V. Stein, N. Goodwin, L. Balicer, E. Nolte, and E. Suter. Cham: Springer International Publishing. 209-21.

[17] Armitage, G. D., Suter, E., Oelke, N. D., and Adair, C. E.
2009. "Health Systems Integration: State of the Evidence." International Journal of Integrated Care 9 (2). Accessed September 23, 2016. http://www.ijic.org/articles/10.5334/ijic.316/.

[18] Ling, T., Brereton, L., Conklin, A., Newbould, J., and Roland, M. 2012. "Barriers and Facilitators to Integrating Care: Experiences from the English Integrated Care Pilots.” International Journal of Integrated Care 12 (5). Accessed September 23, 2016. http://www.ijic.org/articles/abstract/10.5334/ijic.982/.

[19] Eijkelberg, I. M., Spreeuwenberg, C., Mur-Veeman, I. M., and Wolffenbuttel, B. H. R. 2001. "From Shared Care to Disease Management: Key-Influencing Factors." International Journal of Integrated Care 1 (1). Accessed September 23, 2016. http://www.ijic.org/articles/10.5334/ijic.22/.

[20] Goodwin, N. 2013. “Taking Integrated Care Forward: The Need for Shared Values.” International Journal of Integrated Care 13 (2). Accessed September 16, 2016. http://www.ijic.org/articles/10.5334/ijic.1180/.

[21] Brown, L. V. 2007. Psychology of Motivation. New York: Nova Science Publishers.

[22] Kalat, J. W., ed. 2011. Introduction to Psychology. Wadsworth: Cengage Learning.

[23] Comelli, G., von Rosenstiel, L., and Nerdinger, F. W., eds. 2014. Führung Durch Motivation. Mitarbeiter Für Die Ziele Des Unternehmens Gewinnen. München: Vahlen.

[24] Dolea, C., and Adams O. 2005. "Motivation of Health Care Workers-Review of Theories and Empirical Evidence." Cahiers de Sociologie et de Démograhie Médicales 45 (1): 135-61.

[25] Maslow, A. H. 1954. Motivation and Personality. New York: Harper Row.

[26] Herzberg, F., Mausner, B., and Snyderman, B. B., eds. 1967. The Motivation to Work. New York: Wiley.

[27] Aderfer, C. P. 1972. Existence, Relatedness \& Growth. New York: Free Press.

[28] McClelland, D. C. 1985. Human Motivation. Glenwood: Scott-Foresman.

[29] Weinert, A. B., ed. 2004. Organisations-und Personalpsychologie. Basel: Belz.

[30] Herzberg, F. 2003. "One More Time: How Do You Motivate Your Employees?” Harvard Business Review 81 (1): 87-96.

[31] Ratanawongsa, N., Howell, E. E., and Wright, S. M. 2006. "What Motivates Physicians throughout Their Careers in Medicine?” Comprehensive Therapy 32 (4): 210-7.

[32] Vroom, V. H. 1964. Work and Motivation. New York: Wiley.

[33] Conrad, D., Gosh, A., and Isaacson, M. 2015. "Employee Motivation Factors: A Comparative Study of the 
Perceptions between Physicians and Physician Leaders.” International Journal of Public Leadership 11 (2): 92-106.

[34] Kontodimopoulos, N., Paleologou, V., and Niakas, D. 2009. "Identifying Important Motivational Factors for Professionals in Greek Hospitals.” BMC Health Services Research 9 (164): 1-11.

[35] Zydziunaite, V., and Katiliute, E. 2007. "Improving Motivation among Health Care Workers in Private Health Care Organizations: A Perspective of Nuring Personnel.” Baltic Journal of Management 2 (2): 213-24.

[36] Lambrou, P., Kontodimopoulos, N., and Niakas, D. 2010. "Motivation and Job Satisfaction among Medical and Nursing Staff in a Cyprus Public General Hospital.” Human Resources on Health 8 (26): 1-9.

[37] Cheng, P. L. K., and Robertson, R. W. 2006. "Not for Bread Alone-Motivation among Hospital Employees in Singapore.” Public Organization Review 6: 155-66.

[38] Suter, E., Oelke, N. D., Adair, C. E., and Armitage, G. D. 2009. "Ten Key Principles for Successful Health Systems Integration.” Healthcare Quarterly 13: 16-23.

[39] Dunt, D., Elsworth, G., Southern, D. M., Harris, C., Potiriadis, M., and Young, D. 2006. "Individual and Area Factors Associated with General Practitioner Integration in Austalia: A Multilevel Analysis.” Social Science and Medicine 63: 680-90.

[40] Busetto, L., Lijkx, K., Huizing, A., and Vrijhoef, B. 2015. "Implementation of Integrated Care for Diabetes Mellitus Type 2 by Two Dutch Care Groups: A Case Study.” BMC Family Practice 16 (105). Accessed September 15, 2016. https://www.ncbi.nlm.nih.gov/pmc/articles/PMC4546228 /.

[41] Appleby, N. J., Dunt, D., Southern, D. M., and Young, D. 1999. “General Practice Integration in Australia. Primary Health Services Provider and Consumer Perceptions of Barriers and Solutions.” Australian Family Physician 28: 858-63.

[42] Anderson, S. 1998. "How Healthcare Organizations can Achieve True Integration.” Healthcare Financial
Management 52: 31-4.

[43] Southern, D. M., Young, D., Dunt, D., Appleby, N. J., and Batterham, R. W. 2002. "Integration of Primary Health Care Services: Perceptions of Australian General Practitioners, Non-general Practitioner Health Service Providers and Consumers at the General Practice-Primary Care Interface.” Evaluation Program Planning 25: 47-59.

[44] Evans, J. M. 2014. "Health Systems Integration: Competing or Shared Mental Models?” International Journal of Integrated Care 14 (4). Accessed September 15, 2016. http://www.ijic.org/articles/10.5334/ijic.1578/.

[45] Purohit, B., Maneskar, A., and Saxena, D. 2016. "Developing a Tool to Assess Motivation among Health Service Providers Working with Public Health System in India.” Human Resources on Health 14 (15). Accessed September 16, 2016. http://download.springer.com/static/pdf/260/art\%253A10. 1186\%252Fs12960-016-0111-1.pdf?originUrl=http\%3A \%2F\%2Fhuman-resources-health.biomedcentral.com\%2F article\%2F10.1186\%2Fs12960-016-0111-1\&token2=exp $=1486379118$ acl=\%2Fstatic\%2Fpdf\%2F260\%2Fart\%25 253A10.1186\%25252Fs12960-016-0111-1.pdf* hmac=7 393c071c803b1b2364dc9cb77d1ef687123d389b0e39dea 6b7ec02238a3e8a8.

[46] De Oliveira-Vasconcelos-Filho, P., De Souza, M. R., Mangeon, E. P. E., and D’Ávila-Viana, A. L. 2016. "Physicians' Job Satisfaction and Motivation in a Public Academic Hospital." Human Resources on Health 14 (75). Accessed September 16, 2016. https://human-resources-health.biomedcentral.com/track/ pdf/10.1186/s12960-016-0169-9?site=human-resources-h ealth.biomedcentral.com.

[47] Unterweger, M., Imhof, S., Mohr, H., Römpler, M., and Kubik-Huch, R. A. 2007. "Welche Faktoren Beeinflussen die Arbeitszufriedenheit und -Motivation an Einem Institut für Radiologie?” PRAXIS 96 (35): 1299-306.

[48] Elizur, D., Borg, I., Hunt, R., and Beck, I. M. 1991. "The Structure of Work Values: A Cross Cultural Comparison.” Public Personnel Management 12 (1): 21-38. 